\title{
Ice flow dynamics and surface meltwater flux at a land-terminating sector of the Greenland ice sheet
}

\author{
Andrew A.W. FITZPATRICK, ${ }^{1}$ Alun HUBBARD, ${ }^{1}$ Ian JOUGHIN, ${ }^{2}$ Duncan J. QUINCEY, ${ }^{3}$ \\ Dirk VAN AS, ${ }^{4}$ Andreas P.B. MIKKELSEN, ${ }^{5}$ Samuel H. DOYLE, ${ }^{1}$ Bent HASHOLT, ${ }^{5}$ \\ Glenn A. JONES ${ }^{1}$
}

${ }^{1}$ Center for Glaciology, Institute of Geography and Earth Sciences, Aberystwyth University, Aberystwyth, UK E-mail: aaf07@aber.ac.uk ${ }^{2}$ Polar Science Center, University of Washington, Seattle, WA, USA

${ }^{3}$ School of Geography, University of Leeds, Leeds, UK

${ }^{4}$ Geological Survey of Denmark and Greenland (GEUS), Copenhagen, Denmark

${ }^{5}$ Department of Geography and Geology, University of Copenhagen, Copenhagen, Denmark

\begin{abstract}
We present satellite-derived velocity patterns for the two contrasting melt seasons of 200910 across Russell Glacier catchment, a western, land-terminating sector of the Greenland ice sheet which encompasses the $\mathrm{K}$ (angerlussuaq)-transect. Results highlight great spatial heterogeneity in flow, indicating that structural controls such as bedrock geometry govern ice discharge into individual outlet troughs. Results also reveal strong seasonal flow variability extending $57 \mathrm{~km}$ up-glacier to $1200 \mathrm{~m}$ elevation, with the largest acceleration $(100 \%$ over 11 days) occurring within $10 \mathrm{~km}$ of the margin coincident with spring melt. By late July 2010, 2 weeks before peak melt and runoff, $48 \%$ of the $2400 \mathrm{~km}^{2}$ catchment had slowed to less than the winter mean. This observation supports the hypothesis that the subglacial hydrological system evolves from an inefficient distributed to an efficient drainage system, regulating flow dynamics. Despite this, the cumulative surface flux over the record melt year of 2010 was still greater compared with the perturbation over the average melt year of 2009. This study supports the proposition that local surface meltwater runoff couples to basal hydrology driving ice-sheet dynamics, and although the effect is nonlinear, our observations indicate that greater meltwater runoff yields increased net flux over this sector of the ice sheet.
\end{abstract}

\section{INTRODUCTION}

Enhanced surface meltwater runoff since the 1960s (Hanna and others, 2005) has been implicated in ice flow acceleration across the margins of the Greenland ice sheet (GrIS) (Rignot and Kanagaratnam, 2006). This association has led to the concept of a direct hydromechanical link between the ice-sheet surface and its bed (Zwally and others, 2002), a process well understood on valley glaciers but that until the last decade was undocumented on ice sheets. Covariations in ice velocity and surface uplift have been shown to lag peak daily melt in summer (Van de Wal and others, 2008; Shepherd and others, 2009) and occur during discrete pulses of rapid supraglacial lake drainage (Das and others, 2008; Doyle and others, 2012).

RADARSAT interferometric synthetic aperture radar (InSAR) and GPS measurements covering the western margin of the GrIS confirm patterns of seasonal speed-up (Joughin and others, 2008; Bartholomew and others, 2011; Palmer and others, 2011). However, differences exist regarding the magnitude as well as the spatial and temporal patterns of these flow perturbations. Short-lived high-magnitude diurnal and seasonal increases in velocity $(\sim 220 \%$ above the winter mean) have been recorded (Shepherd and others, 2009; Bartholomew and others, 2010, 2011); however, a strong contrast between the duration of peak summer flow and the strength of the melt season (Sundal and others, 2011) suggests the relationship between melt intensity and annual ice flux is more complex than originally thought. Long-term
GPS measurements in this region have revealed a significant decrease in mean surface velocity despite increased ablation over a 17 year time-span (Van de Wal and others, 2008). A decade's worth of satellite derived velocity data encompassing nearly all of Greenland's outlet glaciers (200+) show complex spatial and temporal patterns of ice flow, highlighting the contrasting ice dynamics of land- and marineterminating outlets (Moon and others, 2012). Although investigations of individual glaciers using GPS surveys reveal a great deal about glacier behavior on short and interannual timescales, understanding the complex spatiotemporal behavior of the GrIS cannot be achieved without the help of satellite imagery.

Here we present high-resolution, 11 day repeat interval ice surface velocity maps covering Russell Glacier and three adjacent outlet glaciers (Fig. 1) during two melt seasons of contrasting intensity: the record high melt year of 2010, and the comparatively low melt year of 2009 (termed average by Van As and others, 2012).

\section{STUDY AREA}

Russell Glacier is a land-terminating outlet glacier in West Greenland $\left(67^{\circ} \mathrm{N}, 50^{\circ} \mathrm{W}\right.$; Fig. 1$)$ that has received considerable scientific attention given its ease of access from nearby Kangerlussuaq. This land-terminating outlet is isolated from marine influences and exhibits changes in ice dynamics that are remote from tidewater influences and are directly attributable to surface melt forcing. 


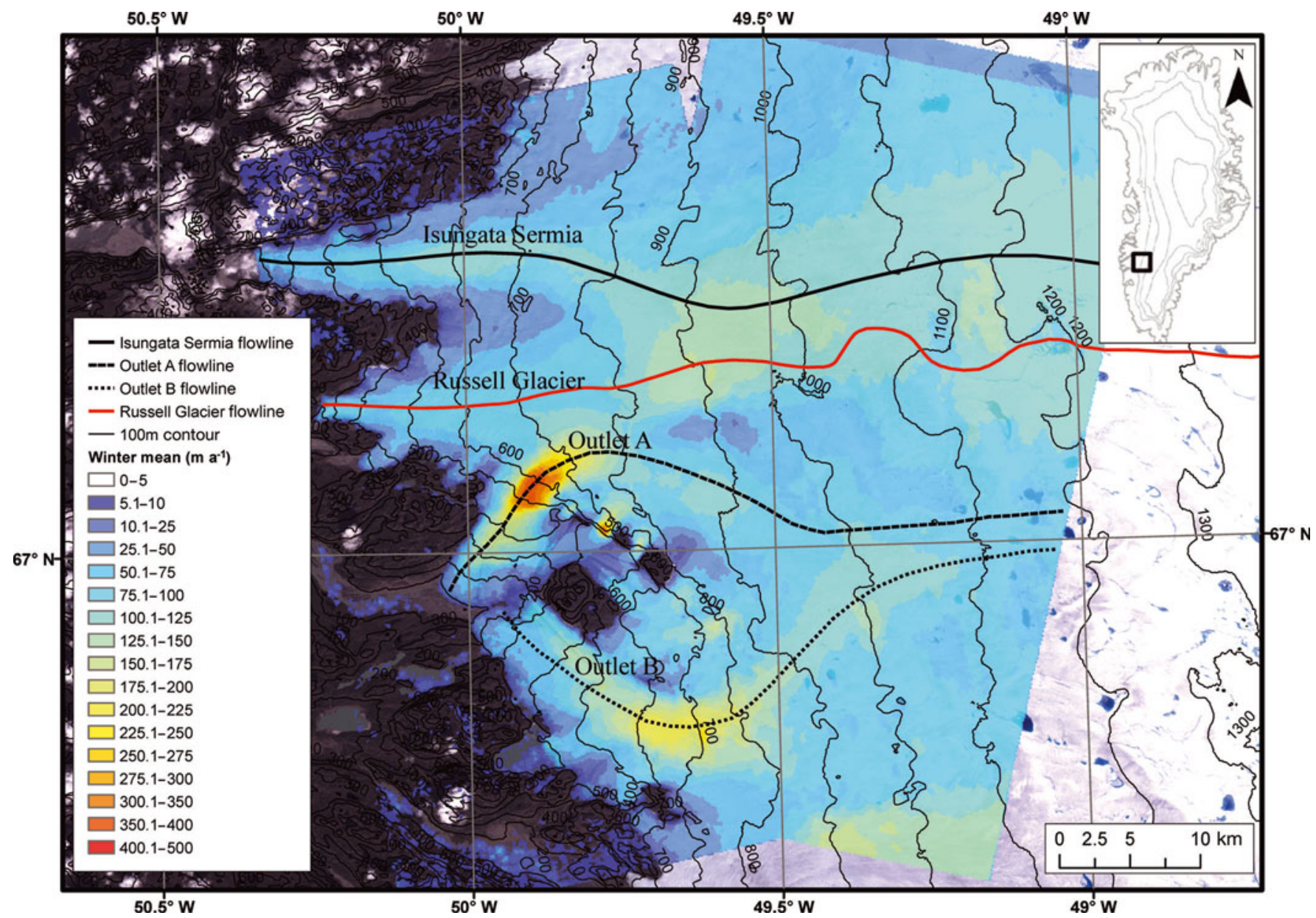

Fig. 1. Winter mean (2009 and 2010) velocity map for our study area derived from TSX data overlaid onto a Landsat 7 image from June 2008. The central flowline of Russell Glacier visible is shown in red, with flowlines of neighboring glaciers Isungata Sermia, outlet A and outlet B shown in black. The winter mean velocity map was derived from TSX data with mid-dates 11 November 2009, 7 February 2010, 9 November 2010 and 20 November 2010. Elevation contours were derived from a 2008 SPOT DEM.

\section{METHODS}

TerraSAR-X (TSX) data were acquired in StripMap mode producing images with $30 \times 50 \mathrm{~km}$ swaths at $3 \mathrm{~m}$ resolution, with repeat orbits every 11 days (Joughin and others, 2010a). Two overlapping TSX image pairs were used covering an area of $3047 \mathrm{~km}^{2}$ including an ice extent of $2400 \mathrm{~km}^{2}$ (Fig. 1; Table 1a). Envisat advanced synthetic aperture radar (ASAR) data from 2009 were acquired in image mode, with a swath of $56-100 \mathrm{~km}$, a repeat orbit time of 35 days and a $30 \mathrm{~m}$ spatial resolution (Table 1b). Additionally, panchromatic Landsat Thematic Mapper (TM)/Enhanced TM Plus (ETM+) and multispectral Advanced Spaceborne Thermal Emission and Reflection Radiometer (ASTER) scenes were acquired. Both Landsat and ASTER have a $15 \mathrm{~m}$ spatial resolution and 16 day repeat interval (Table 1c).

Velocity data were derived from TSX datasets using a combination of conventional interferometry and speckletracking techniques (Joughin, 2002). Interferograms were produced using Gamma software (Werner and others, 2001) where baselines were estimated by least-square fit from off-ice control points. Cross-correlation (speckle-tracking) procedures were used to estimate the range and azimuth offsets between interferometric pairs to determine displacements with sub-pixel accuracy. Error margins in the TSX velocity data were estimated to be $\pm 5 \mathrm{ma}^{-1}$ by measuring the mean difference from zero of stationary (off-ice) areas in each of the images. Additional velocity data from cross-correlation feature-tracking techniques using Envisat ASAR data (Table 1b) in Gamma, and panchromatic Landsat and ASTER scenes (Table 1c) in COSI-CORR software (Leprince and others, 2007) were derived to fill gaps in the temporal coverage of TSX data during 2009. Feature tracking relies on finding the best-fit positions between search windows from two images allowing surface displacement to be derived. This method is described in detail by Strozzi and others (2002) and has been successfully applied to outlet glaciers in East Greenland (Luckman and others, 2003). In this study, search window sizes of 64 pixels were used, which strike a balance between accommodating for the maximum expected displacement between image pairs and exploiting the spatial coverage. Although the spatial resolution is $15 \mathrm{~m}$, we co-register the images with sub-pixel accuracy to produce velocity results with uncertainties in the order of $30 \mathrm{~m} \mathrm{a}^{-1}$, derived by measuring static, off-ice displacement.

Surface runoff is derived from a surface energy-balance model described in detail by Van As and others (2012), utilizing data from a network of automated weather stations. The model uses temperature, air pressure, humidity, wind speed, and the downwelling components of shortwave radiation and longwave radiation to calculate the surface energy budget components (absorbed shortwave radiation, net longwave radiation, sensible heat flux, latent heat flux and subsurface heat flux). The net residual positive energy flux excess is applied to melting snow and ice, allowing 
Table 1. Temporal coverage, image IDs and details of (a) the TSX dataset, (b) Envisat ASAR data and (c) ASTER and Landsat data. Date format is day/month/year

(a)

\begin{tabular}{llllll}
\hline Start date $\quad$ End date & Time & Path direction & Beam ID $\quad$ Relative orbit Incidence angle & Mid date & $\begin{array}{c}\text { Catchment } \\
\text { coverage }\end{array}$
\end{tabular}

\begin{tabular}{lcclccccc}
\hline 20/03/09 & $31 / 03 / 09$ & $20.49 / 09: 57$ & Asc./desc. & $013 / 009$ & $103 / 96$ & $41.69 / 34.01$ & $25 / 03 / 09$ & Both \\
$30 / 07 / 09$ & $10 / 08 / 09$ & $20.49 / 09: 57$ & Asc./desc. & $013 / 009$ & $103 / 96$ & $41.69 / 34.01$ & $04 / 08 / 09$ & Both \\
$10 / 08 / 09$ & $21 / 08 / 09$ & $20.49 / 09: 57$ & Asc./desc. & $013 / 009$ & $103 / 96$ & $41.69 / 34.01$ & $15 / 08 / 09$ & Both \\
$21 / 08 / 09$ & $01 / 09 / 09$ & $20.49 / 09: 57$ & Asc./desc. & $013 / 009$ & $103 / 96$ & $41.69 / 34.01$ & $26 / 08 / 09$ & Both \\
$06 / 11 / 09$ & $17 / 11 / 09$ & $20.49 / 09: 57$ & Asc./desc. & $013 / 009$ & $103 / 96$ & $41.69 / 34.01$ & $11 / 11 / 09$ & Both \\
$02 / 02 / 10$ & $13 / 02 / 10$ & $09: 57$ & Descending & 009 & 96 & 34.01 & $07 / 02 / 10$ & Upper \\
$20 / 04 / 10$ & $01 / 05 / 10$ & 20.49 & Ascending & 013 & 103 & 41.69 & $25 / 04 / 10$ & Lower \\
$01 / 05 / 10$ & $12 / 05 / 10$ & $20.49 / 09: 57$ & Asc./desc. & $013 / 009$ & $103 / 96$ & $41.69 / 34.01$ & $06 / 05 / 10$ & Both \\
$14 / 06 / 10$ & $25 / 06 / 10$ & 20.49 & Ascending & 013 & 103 & 41.69 & $19 / 06 / 10$ & Lower \\
$25 / 06 / 10$ & $06 / 07 / 10$ & 20.49 & Ascending & 013 & 103 & 41.69 & $30 / 06 / 10$ & Lower \\
$06 / 07 / 10$ & $17 / 07 / 10$ & 20.49 & Ascending & 013 & 103 & 41.69 & $11 / 07 / 10$ & Lower \\
$17 / 07 / 10$ & $28 / 07 / 10$ & 20.49 & Ascending & 013 & 103 & 41.69 & $22 / 07 / 10$ & Lower \\
$19 / 08 / 10$ & $30 / 08 / 10$ & $09: 57$ & Descending & 009 & 96 & 34.01 & $24 / 08 / 10$ & Upper \\
$30 / 08 / 10$ & $10 / 09 / 10$ & 20.49 & Ascending & 013 & 103 & 41.69 & $05 / 09 / 10$ & Lower \\
$24 / 10 / 10$ & $04 / 11 / 10$ & $20.49 / 09: 57$ & Asc./desc. & $013 / 009$ & $103 / 96$ & $41.69 / 34.01$ & $29 / 10 / 10$ & Both \\
$04 / 11 / 10$ & $15 / 11 / 10$ & 20.49 & Ascending & 013 & 103 & 41.69 & $09 / 11 / 10$ & Lower \\
$15 / 11 / 10$ & $26 / 11 / 10$ & $20.49 / 09: 57$ & Asc./desc. & $013 / 009$ & $103 / 96$ & $41.69 / 34.01$ & $20 / 11 / 10$ & Both \\
\hline
\end{tabular}

(b)

\begin{tabular}{|c|c|c|c|c|c|c|c|c|}
\hline Start date & End date & Time & Path direction & Track & Starting orbit & Swath & Mid-date & $\begin{array}{c}\text { Catchment } \\
\text { coverage }\end{array}$ \\
\hline 19/04/09 & 24/05/09 & $00.22: 03$ & Ascending & 174 & 37302 & & 06/05/09 & Lower \\
\hline 24/05/09 & 28/06/09 & $00.22: 04$ & Ascending & 174 & 37803 & 12 & 10/06/09 & Lower \\
\hline 01/07/09 & 05/08/09 & $00.27: 48$ & Ascending & 217 & 38347 & & 18/07/09 & Lower \\
\hline
\end{tabular}

(c)

\begin{tabular}{llcr}
\hline Start date & End date & Satellite & $\begin{array}{c}\text { Mid-date } \\
\text { Catchment }\end{array}$ \\
\hline $11 / 06 / 09$ & $27 / 06 / 09$ & ASTER & $19 / 06 / 09$ \\
$13 / 06 / 09$ & $15 / 07 / 09$ & Landsat & $29 / 06 / 09$ \\
\hline
\end{tabular}

surface melt to be calculated, with error margins of $\pm 15 \%$ (Van As and others, 2012). We compare the modeled surface runoff to the proglacial discharge measured at Watson River bridge (Hasholt and others, 2012).

\section{RESULTS}

Surface velocity maps produced by the TSX data reveal complex spatial and temporal patterns of ice flow within Russell Glacier catchment (Fig. 2). To illustrate these patterns, surface velocity profiles for Russell Glacier, Isungata Sermia and two unnamed outlets, referred to as outlets A and B herein (Fig. 1), were extracted. The flowlines were determined from a combination of (1) structural mapping from high-resolution Satellite Pour l'Observation de la Terre (SPOT) images acquired in 2008, (2) velocity maps from previous studies (Palmer and others, 2011; Sundal and others, 2011) and (3) a preliminary basal digital elevation model (DEM) (personal communication from
R. Pettersson, 2010). Velocities extracted along the flowline of Russell Glacier exhibit great temporal variation, with seasonal changes extending at least as far inland as $57 \mathrm{~km}$, the limit of our velocity coverage (Fig. 2). Mean winter velocities for Russell Glacier are $\sim 100 \mathrm{~m} \mathrm{a}^{-1}$ (Fig. 3), with summer speeds exceeding $200 \mathrm{~m} \mathrm{a}^{-1}$. All four of the outlet glaciers have similar hypsometry (Fig. 3); however, the extent and magnitude of accelerated flow exhibited by each outlet varies significantly. High-magnitude perturbations in ice flow experienced by outlets A and B $(\sim 200 \%$ and $\sim 300 \%$ respectively) sharply contrast with the relatively modest (100-150\%) increase in ice flow from Isungata Sermia and Russell glaciers in May 2010 (Fig. 4). By June 2010, mean surface velocities of outlet $A$ had returned to or dropped below the winter mean, while the other outlets were still experiencing accelerated flow. In contrast to Russell Glacier, ice flow within the first $400 \mathrm{~m}$ elevation of Isungata Sermia continued at elevated rates above the winter mean for a longer period of the summer (Fig. 4). 

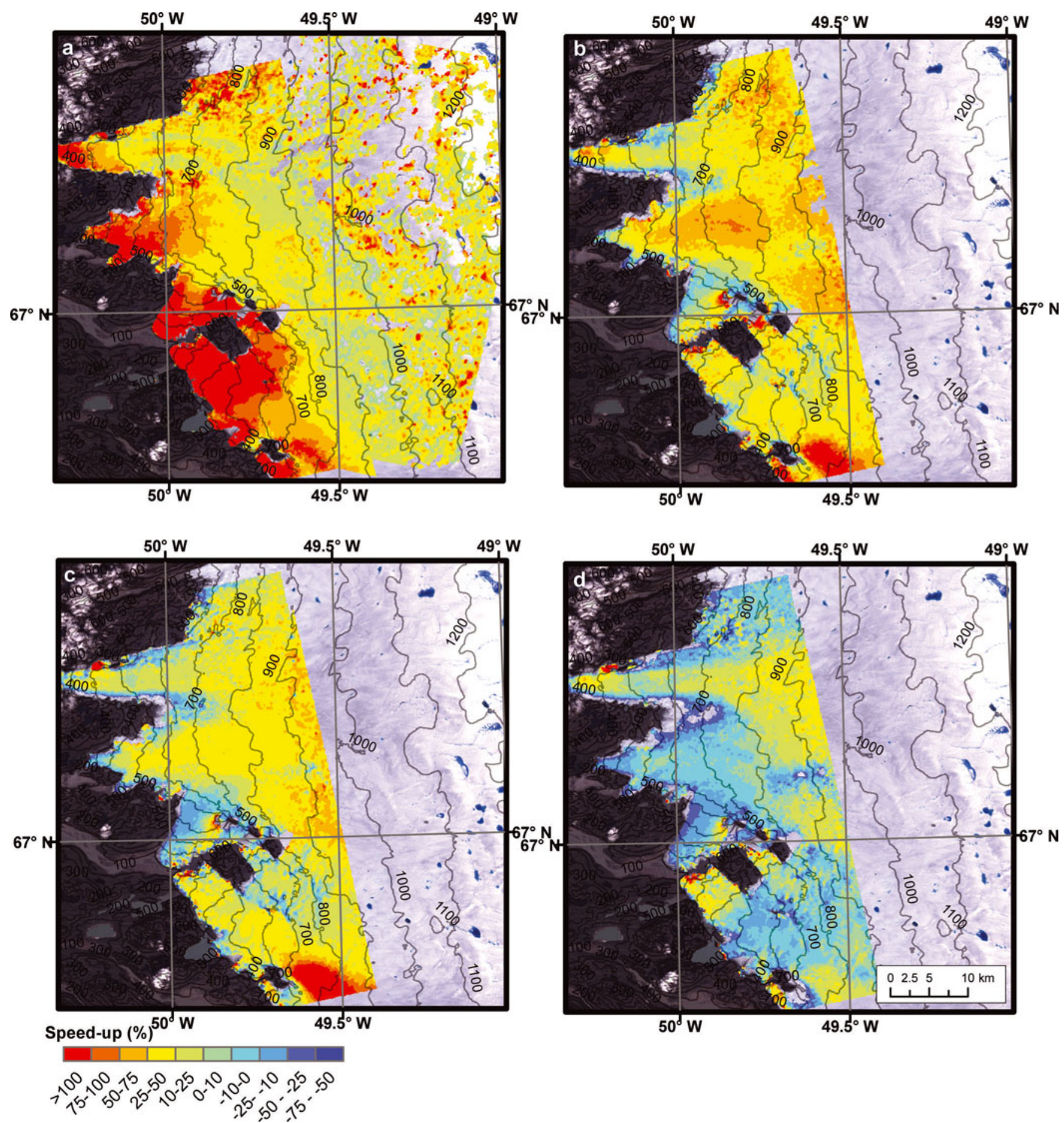

Fig. 2. Surface velocities expressed as a percentage relative to the winter mean throughout summer 2010 over 11 day periods with midpoints (a) 6 May, (b) 19 June, (c) 30 June and (d) 22 July. Elevation contours derived from a SPOT DEM are also shown.

To highlight spatial and temporal changes between 2009 and 2010, the flowline of Russell Glacier is split into three zones, the lower $(400-600 \mathrm{~m} / 0-10 \mathrm{~km})$, middle $(600-800 \mathrm{~m} /$ $10-21 \mathrm{~km})$ and upper $(800-1000 \mathrm{~m} / 21-34 \mathrm{~km})$. In early May 2010, surface velocities in the lower portion of the ice-sheet margin doubled relative to the winter mean (Figs 2 and 5). Following the initial perturbation, velocities reduced and ice flow increased in the middle and upper marginal zones. Ice surface velocities derived from TSX data reveal a sustained (11 day average) peak of $249 \mathrm{~m} \mathrm{a}^{-1}$ around 19 June 2010, $26 \mathrm{~km}$ from the ice margin. Following this, ice flow decreased and returned to or dropped below the winter mean during July and August. A similar pattern occurred in
2009; however, the lack of temporal coverage of satellite observations during early summer prevents us from determining the exact time of peak flow. Owing to the paucity of data in the velocity record during May 2009, the initiation of accelerated flow (defined as ice flow 50\% winter mean; Fig. 2) was derived from geodetic GPS stations located within the equivalent elevation zones (S. Doyle, unpublished data) and is in agreement with Bartholomew and others (2011). Velocity results from mid- and late June 2009 capture the tail end of summer acceleration as ice flow steadily returned to winter values. Changes also occurred throughout the winter months along the Russell Glacier flowline, and mean velocities increased by $6 \%$ over the 


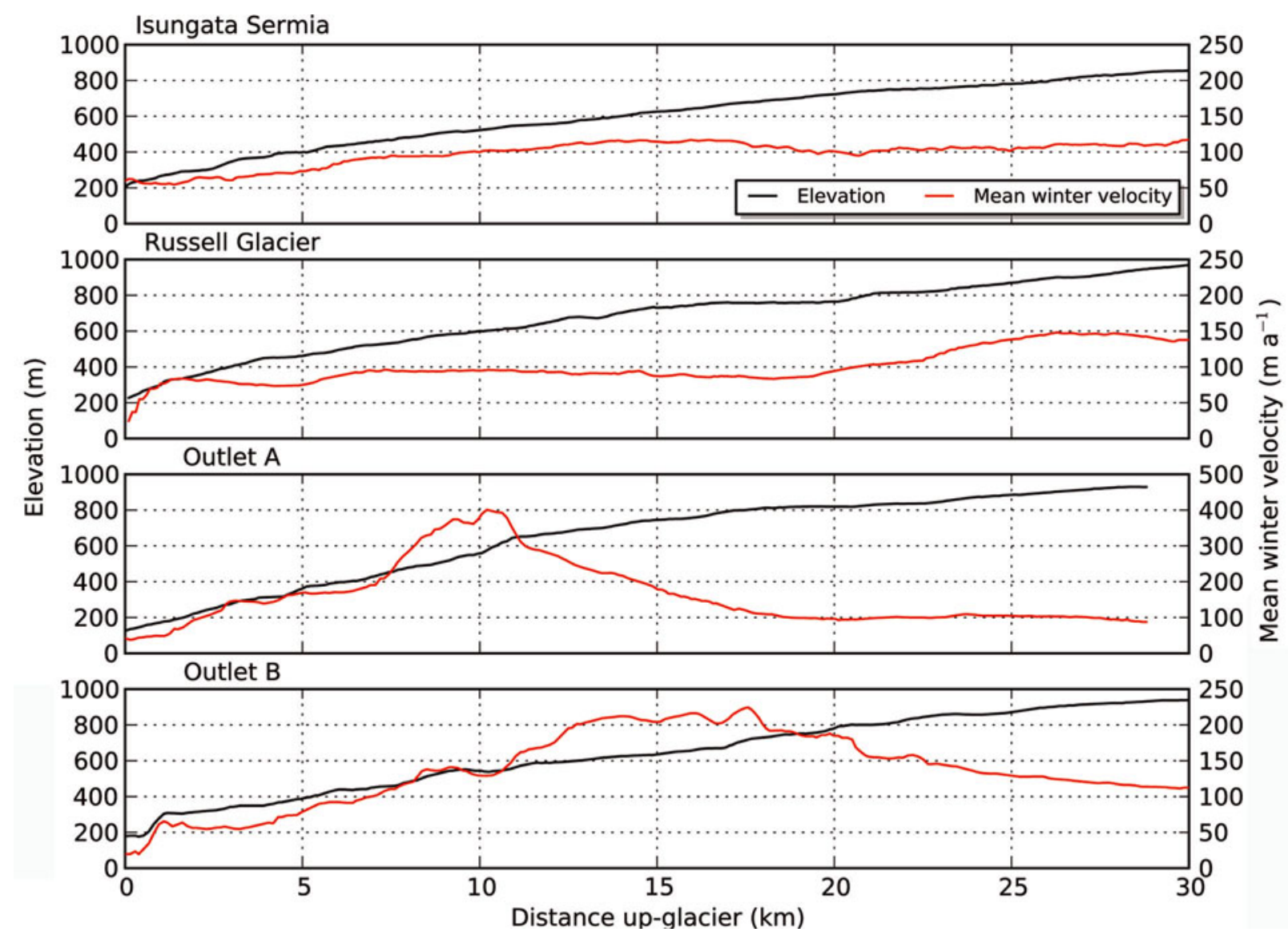

Fig. 3. Surface elevation $(\mathrm{m})$ and mean winter velocities $\left(\mathrm{m} \mathrm{a}^{-1}\right)$ of the four outlet glaciers Isungata Sermia, Russell Glacier, outlet $\mathrm{A}$ and outlet B, derived from the flowlines shown in Figure 1. Winter mean was derived from TSX data with mid-dates 11 November 2009, 7 February 2010, 9 November 2010 and 20 November 2010.

course of the 2009 winter (November 2009 to February 2010). In the upper zone, velocities in February 2010 were $22 \%$ greater at the end of winter compared to values from the start of winter the same year (November 2010), and in 2009, over the entire $57 \mathrm{~km}$ transect, mean velocities in March were $9 \%$ greater than in November the same year. In both years a linear trend exists of decreasing magnitude of winter speed-up with increasing elevation.

The energy-balance model reveals that, over the lower zone of the catchment, surface melting initiated on 16 May 2009 and 2 May 2010 and continued for 125 and 177 days respectively. The extended period of melt (a difference of 52 days) is due to the record-breaking temperatures during 2010 (2.7 standard deviations above the 1974-2010 mean), combined with low winter accumulation and low surface albedo (Van As and others, 2012). The year 2010 is herein referred to as a 'high melt year', and is compared to the low melt year of 2009 (termed near-average by Van As and others, 2012). To illustrate the contrasting character in ice flow between years, the results are expressed as percentage change in surface velocity relative to the winter mean, since the start of the respective melt seasons (Fig. 5). The winter mean is common to both years to allow absolute comparison, and was derived from TSX data with mid-dates 11 November 2009, 7 February 2010, 9 November 2010 and 20 November 2010.

Accelerated ice flow occurs in 2010 just 4 days after the onset of surface melt at the ice-sheet margin (Figs 2 and 5). Ice in the lower ablation zone experiences the greatest flow increase, doubling in early May, after which the lower zone slows to winter mean levels by mid-July. Ice flow in the middle and upper zones also exhibits an initial period of accelerated flow shortly after the onset of melt, albeit of a reduced magnitude (to 50\%) and up to 48 days after the onset of melt. The increase in annual ice flux $(\Delta v)$ from summer ice velocity variations is expressed as the percentage by which the annual surface displacement exceeds that which would occur if winter values remained constant throughout the year (Fig. 5; Table 2). During 2010, $\Delta v$ values vary from $12 \%$ in lower zones to $15 \%$ in the upper zones of the catchment. It is clear that the magnitude and extent of accelerated flow in 2010 exceeded that of 2009 in the lower and upper zones of the catchment (Fig. 5). In both 2009 and 2010, surface velocity in the lower zone of the catchment slowed and returned to overwinter levels $\sim 90$ and $\sim 80$ days after melt onset respectively (Table 2 ). In the upper zone there are further differences in the seasonal extent of accelerated flow between the years. In 2010, ice in the upper zone continued to flow $20 \%$ greater than the winter mean 114 days after the initiation of the melt season, dropping to winter values after $\sim 125$ days. By contrast, in 2009 , ice in the same elevation band had already returned to winter values within 102 days of melt onset (Fig. 5).

Although flow in early May 2010 doubled relative to the winter mean, this was restricted to $12 \%$ of the $2400 \mathrm{~km}^{2}$ catchment (Fig. 6), with the majority of the survey area (35\%) flowing 25-50\% faster than the winter mean. During June 2010 the majority of the catchment (42\%) continued to flow at speeds $25-50 \%$ greater than the winter mean, with $7 \%$ and $12 \%$ of the area flowing at speeds less than the 


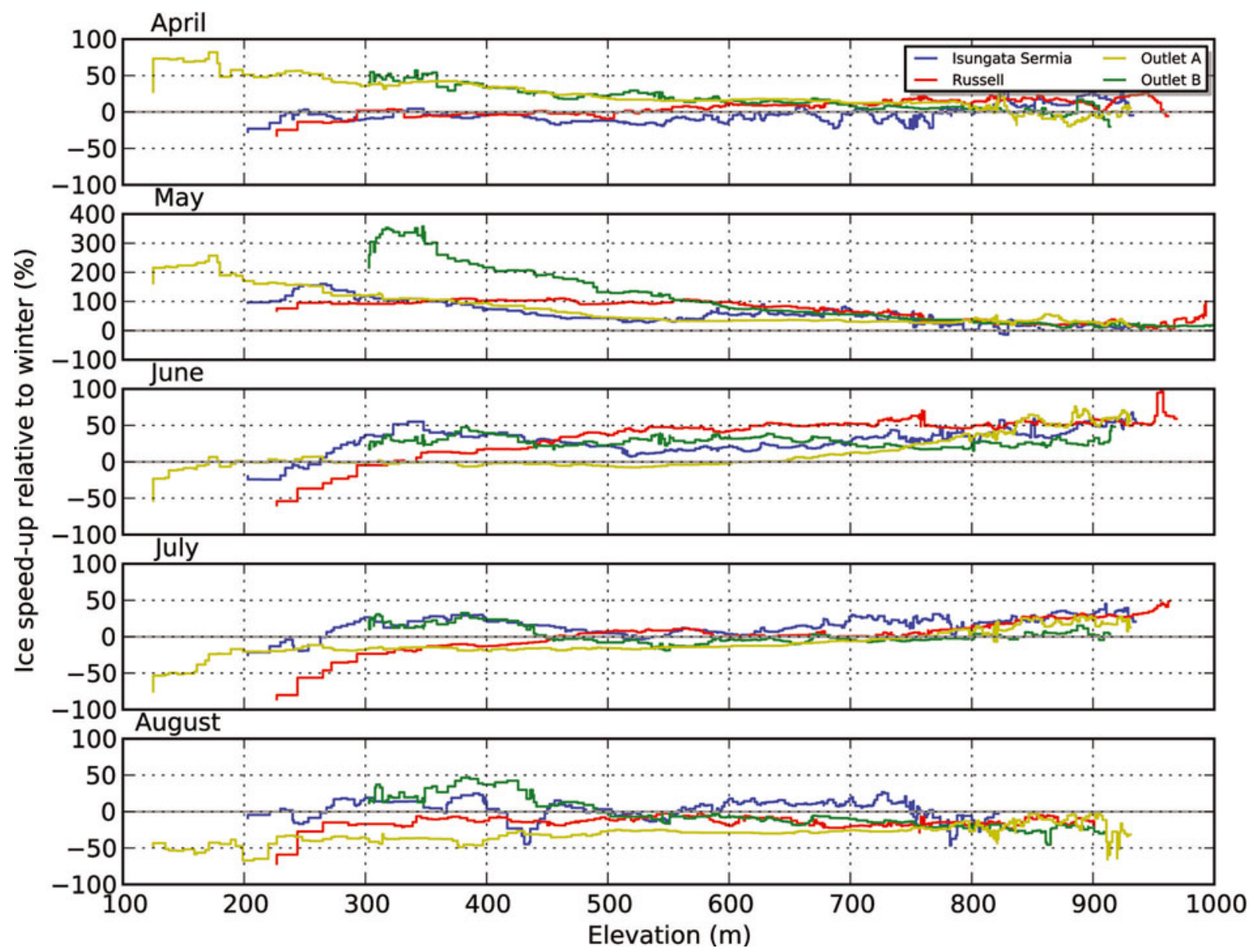

Fig. 4. Mean ice speed-up relative to winter mean of Russell Glacier's neighboring outlets during 2010 in April, May, June, July and August. The flowlines of each of the outlets are shown in Figure 1, and the winter background is shown in Figure 3. Note the different scale in May to accommodate the considerable speed-up ( 300\%) of outlet B.

winter mean (19 and 30 June 2010 respectively). Throughout July 2010 the areal extent of ice flowing slower than the winter mean increased significantly (Table 3), and slowest velocities are obtained at the end of July when $48 \%$ of the catchment flowed at velocities less than the winter mean.

To highlight the differences in the magnitude and extent of accelerated flow between 2009 and 2010, mean ice

Table 2. Summary of seasonal characteristics between 2009 and 2010 , illustrating the first day of speed-up $(50 \%$ more than winter mean) after the start of the melt season, calculated annual ice flux and the number of days for velocity to return to background levels following accelerated flow. Due to paucity of velocity data at the start of the 2009 melt season, data denoted with an asterisk are based on S. Doyle (unpublished data) and Bartholomew and others' (2011) 2009 GPS data, which fall into the same elevation bands

Parameter

$$
\begin{aligned}
& \text { Lower Middle Upper } \\
& \text { (400-600 m) (600-800 m) (800-1000 m) } \\
& 200920102009201020092010
\end{aligned}
$$

First day of speed-up $(50 \%-17 *-4-17 *-4=-40$
more than winter mean) Annual ice flux, $\Delta v(\%)$ Time to return to winter velocities (days) speed-up relative to the winter mean along the entire Russell transect is compared with modeled daily runoff and proglacial discharge (Fig. 7). Despite the fact that in 2010 melt continued 53 days (42\%) longer than during 2009, the time taken to return winter velocities is not proportional to this, with only a slight extension in the upper zone (Table 2). Furthermore the magnitude of the speed-up (mean ice flow relative to the winter mean across the entire transect) peaked at $60 \%$ in both years (Fig. 7); however, this persisted for a longer period in 2010 compared to the previous year. In both years accelerated flow does not coincide with peak proglacial discharge, which occurs in mid- to late July when ice flow is returning to winter background levels.

Table 3. Summary of areal extent of ice flow greater or less than the winter mean. Date format is day/month/year

\begin{tabular}{lcc}
\hline Date & $\begin{array}{c}\text { Less than winter mean } \\
\%\end{array}$ & $\begin{array}{c}\text { More than winter mean } \\
\%\end{array}$ \\
\hline $06 / 05 / 10$ & 0 & 100 \\
$19 / 06 / 10$ & 6.9 & 93.1 \\
$30 / 06 / 10$ & 12.1 & 87.9 \\
$11 / 07 / 10$ & 28.7 & 71.3 \\
$22 / 07 / 10$ & 48.3 & 51.7
\end{tabular}




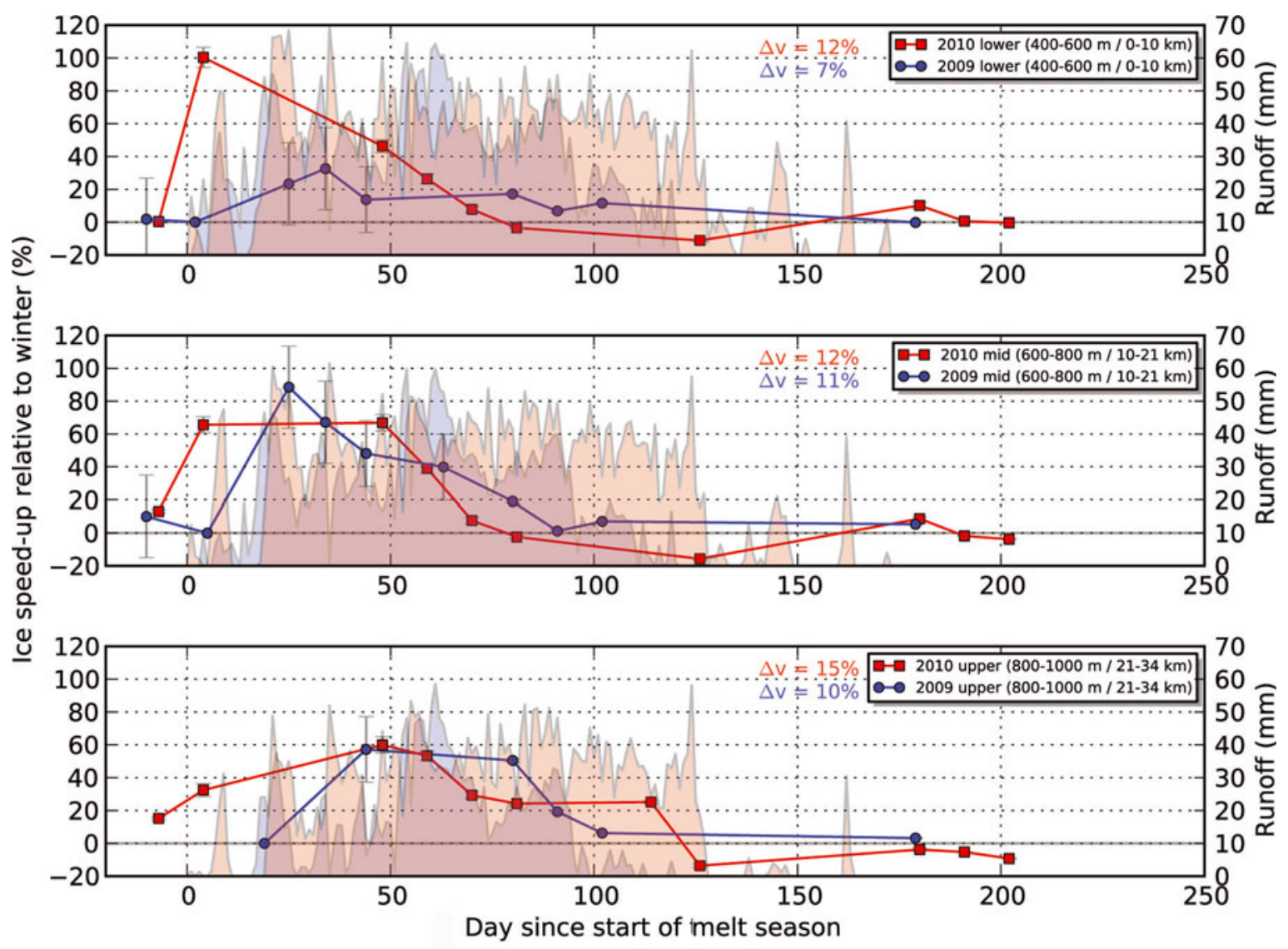

Fig. 5. Ice speed-up relative to winter mean along the Russell Glacier transect since the start of the melt season in 2009 (blue) and 2010 (red) within three zones: lower $(400-600 \mathrm{~m} / 0-10 \mathrm{~km})$, middle $(600-800 \mathrm{~m} / 10-21 \mathrm{~km})$ and upper $(800-1000 \mathrm{~m} / 21-34 \mathrm{~km})$. Owing to paucity of data in the TSX record, the initiation of the speed-up in 2009 was derived from geodetic GPS stations (S. Doyle, unpublished data) in agreement with Bartholomew and others (2011). Modeled daily runoff derived from a network of automated weather stations is also shown within each zone for 2009 (light blue) and 2010 (light red), and overlapping areas are colored light purple. Calculated annual ice flux ( $\Delta v$ ) is shown for each zone.

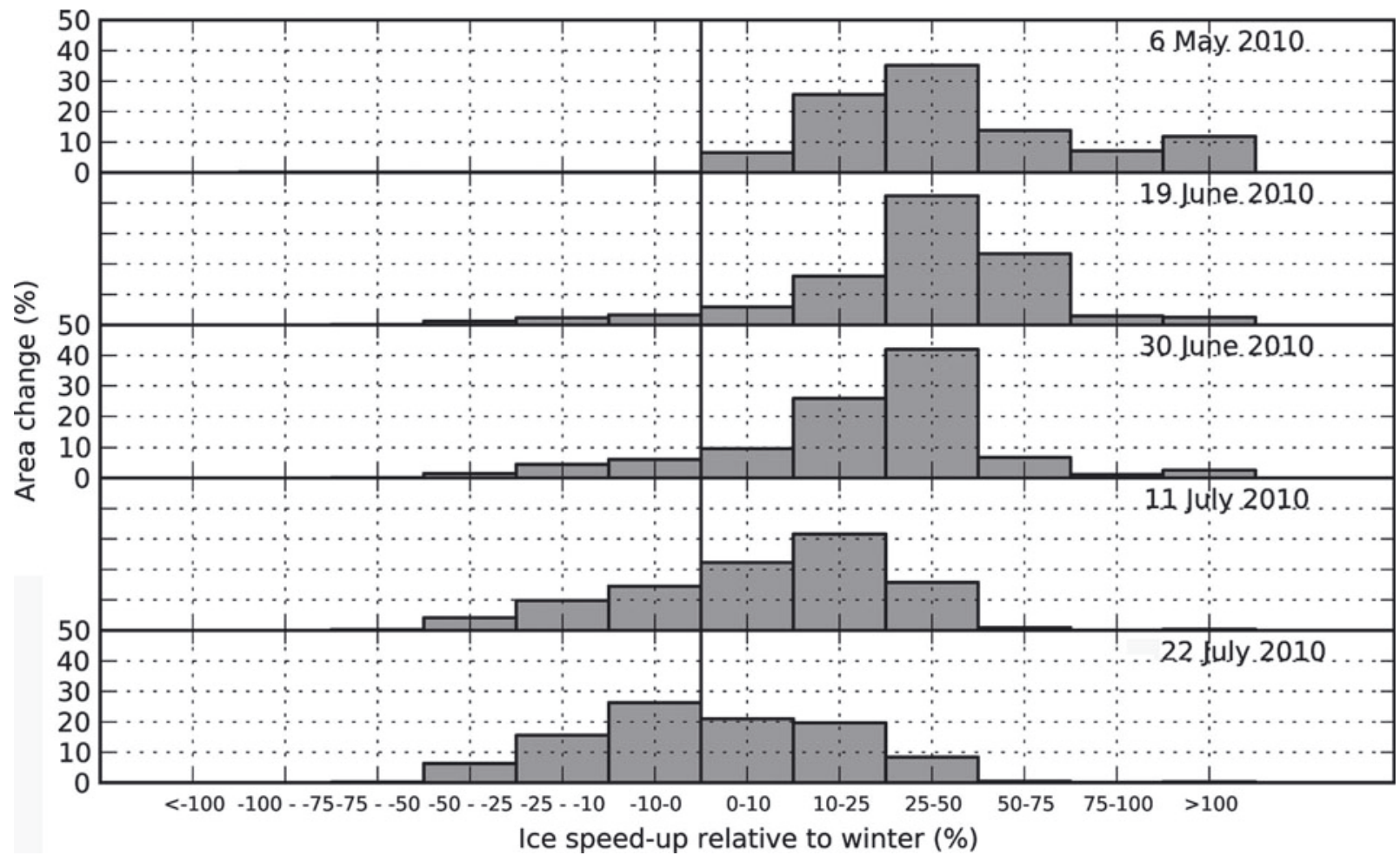

Fig. 6. Changes in the areal extent of the ice speed-up relative to the winter mean. 


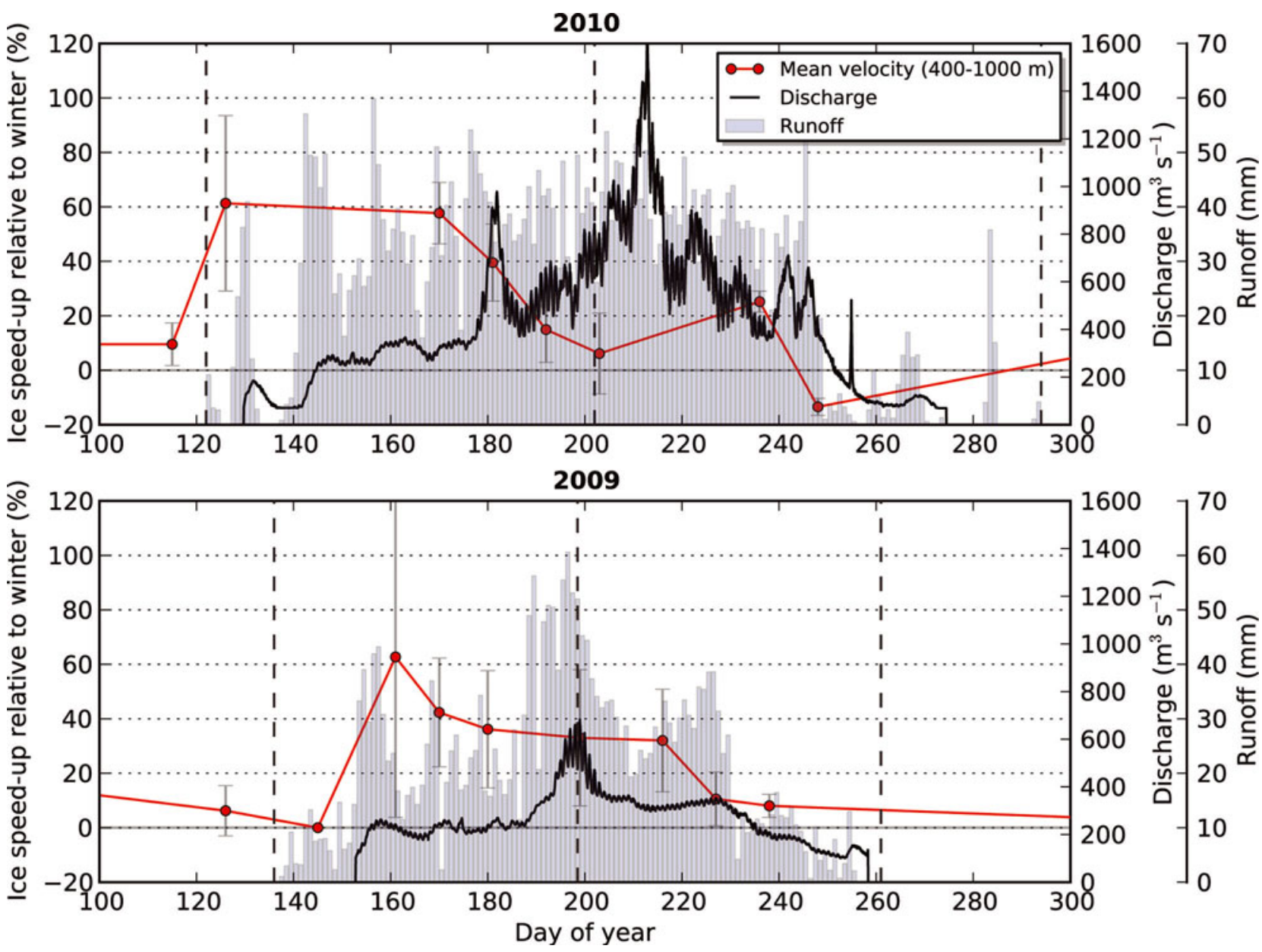

Fig. 7. Mean ice speed-up relative to winter mean along the Russell Glacier transect (400-1000 m/0-34 km) throughout the melt season during 2009 (bottom) and 2010 (top). Error bars represent the standard deviation of velocity covering all elevation bands. Modeled daily runoff (blue bars) (Van As and others, 2012) and discharge (black line) (Hasholt and others, 2012) at the Watson River are also shown for both years.

\section{DISCUSSION}

The time series of residual velocity patterns illustrate a strong seasonal trend extending up to at least $57 \mathrm{~km}(1200 \mathrm{~m}$ elevation) from the ice margin (the limit of our data). The spatial extent of seasonal accelerated ice flow recorded here is in general agreement with previous studies (Van de Wal and others, 2008; Bartholomew and others, 2011; Palmer and others, 2011) and extends beyond the data limits of others (e.g. Joughin and others (2008) and Sundal and others (2011), who identified seasonal patterns up to $1000 \mathrm{~m}$ and $20 \mathrm{~km}$ inland respectively). Consistent with Palmer and others (2011), the velocity patterns (Fig. 2) of this study highlight spatial and temporal heterogeneity indicating that surface velocities are primarily controlled by the local-scale bed topography and the time-varying subglacial drainage network governed by surface meltwater inputs. The extent and magnitude of accelerated flow varies considerably between adjacent outlets (Figs 2 and 4) despite similar hypsometry (Fig. 3) and climatic control. This indicates that subglacial routing of water may, through the influence of basal topography, play a key role in governing individual outlet flow regime. The observed high temporal and spatial variability in ice flow in this study cautions against upscaling dynamic properties of glaciers to larger regions.

A notable feature of our results is the absolute magnitude of the velocity increase in 2010 . Just 4 days after the onset of melt, $12 \%$ of the study area doubled in speed (based on
11 day averaged TSX data; Figs 2, 5 and 6). Previous studies identify summer velocity increases of 30\% (Van de Wal and others, 2008), 50-100\% (Joughin and others, 2008), 50$125 \%$ (Sundal and others, 2011) and 48\% (Palmer and others, 2011). These transient accelerations combine to increase the annual ice flux. Accordingly values of $\Delta v$ for 2010 in the lower zone (12\%) are similar to previous records in this region (17\%; Bartholomew and others, 2011), and are considerably greater than in 2009 (7\%). In the upper zone of the catchment, our results indicate that sustained and widespread melt in 2010 contributed more to the mean annual ice flux (15\%) than in 2009: $10 \%$ in this study compared to $8 \%$ by Bartholomew and others' (2011) GPS measurements). Melt-induced acceleration involves surface meltwater accessing the subglacial system and flowing outwards under pressure, initially through an inefficient system of irregularly distributed channels or linked cavities (Schoof, 2010). When subglacial water pressures approach ice-overburden pressure the ice sheet decouples from its bed, reducing basal friction, permitting enhanced flow via basal sliding. The flow perturbation propagates up-glacier, though the timing and pattern varies each year. In the upper zone the magnitude of melt-induced accelerated flow is reduced and a lag time exists as higher summer temperatures extend to increasingly higher elevations on the ice sheet. Soon after the initial melt-induced acceleration, the speed declines and ice flow in the lower zone returns to, or 
drops below, the winter mean $\sim 90$ and $\sim 80$ days after the onset of melt in 2009 and 2010 respectively. By mid-July 2010, ice in the lower marginal zone, which 2 months earlier experienced the greatest increase in velocity, flowed up to $75 \%$ slower than the winter mean (Figs 2 and 6).

The spatial extent of the deceleration observed after the initial increase in flow (Table 3) suggests a rapid evolution of the subglacial system from an inefficient distributed drainage system into an efficient one. The observed rapid return to winter velocities halfway through the melt season before peak discharge was reached (Fig. 7) supports this hypothesis and indicates that the direct correlation between melt and velocity is short-lived. Previous work suggests that in highmelt years the subglacial hydrology evolves to an efficient channelized state with such rapidity that marginal ice flux is actually reduced in comparison to low-melt years (Sundal and others, 2011). Although rapid deceleration is observed for both years in the lower zone, the results here do not support this pattern. We identified that although the magnitude of the speed-up across the entire transect was similar in both years, accelerated flow persisted for a longer period in 2010 compared to 2009 (Fig. 7). This difference indicates that, in general, the extent and magnitude of meltinduced accelerated flow and therefore the calculated contribution to annual ice flux is greater during a high melt year (2010) than in a comparatively low melt year (2009) (Fig. 5; Table 2). Furthermore, the melt season of 2010 persisted $42 \%$ (53 days) longer than 2009; however, the time taken to return to winter velocities is not proportional to this, with only a slight extension in the upper zone (Table 2). This illustrates that despite the differences between the years, the magnitude and extent of accelerated flow over the entire transect during 2010 is not directly proportional to bulk meltwater runoff and discharge (Fig. 7), indicating that the relationship between meltwater availability and accelerated ice flow is short-lived and nonlinear. Numerical modeling studies have identified a dynamic switching threshold between subglacial drainage modes (Schoof, 2010), with subsequent effect on ice surface velocities, recorded in previous work to be $\sim 1.4 \mathrm{~cm} \mathrm{~d}^{-1}$ (Sundal and others, 2011). Here we have presented evidence of continued accelerated ice flow during periods of melt supply well in excess of this value (Figs 5 and 7), illustrating the complexities of attempting to use simple relationships that fail to take into account the seasonal evolution of the drainage system.

Previous studies illustrate that flow across the ice-sheet margin increases over the winter months (e.g. Joughin and others, 2010b). In the upper zone our data show mean velocities increased by $8 \mathrm{~m} \mathrm{a}^{-1}(6 \%)$ over the course of the $2009 / 10$ winter. We also observed that surface ice flow was $22 \%$ greater at the end of winter (February 2010) compared to the start of winter the same year (November 2010), indicating increased ice flow during freezing surface conditions. Furthermore, in the current study the increase in the recorded velocity over winter was restricted to areas nearer the ice margin (850 m elevation), and little difference was observed at greater elevations, which matches the previously observed trend in this region (Joughin and others, 2010b). Work on temperate glaciers has shown a marked increase in seasonality with distance down-glacier (Hooke and others, 1989), with velocities decreasing over the course of the winter. As winter approaches, the input of meltwater from the supraglacial system subsides as the surface freezes. Over winter, meltwater can be generated at the ice sheet bed through energy supplied by basal shear and geothermal heat (Joughin and others, 2008). Migrating deep pore water from the percolation zone, which persists despite cold conditions in the firn during winter, may also provide an additional source of meltwater (Harper and others, 2012; Humphrey and others, 2012). This water becomes trapped within a distributed drainage system as basal cavities collapse, which over the winter will increase the water pressure at the icebed interface, permitting gradual enhancement of motion.

\section{CONCLUSIONS}

The results of this study provide snapshots of the highly variable ice flow distribution observed at the marginal zone of the GrlS extending at least $57 \mathrm{~km}$ up-glacier. The observed seasonal flow variations are in broad agreement with previous studies (Joughin and others, 2008, 2010b; Bartholomew and others, 2010), though the large initial perturbation followed by rapid deceleration of the ice within the $2400 \mathrm{~km}^{2}$ catchment indicates the basal drainage system responds rapidly to changes in supraglacial inputs. The large spatial variability of the observed velocity trends in this region, highlighted by the differences in ice flow between neighboring outlets, suggests a complex relationship between the routing of water from the surface to the bed and illustrates the importance of considering other forces such as bedrock geometry. Previous work proposes the concept that a positive feedback exists between meltwater production and ice velocity, which would lead to a more rapid response to projected future warming trends (Zwally and others, 2002). However the hydraulic evolution of the basal drainage system acts to regulate ice flow, therefore selflimiting this positive feedback. Recent studies (Sundal and others, 2011) support this hypothesis; in warmer years the period of melt-induced summer acceleration is shorter than in cooler years, as equilibrium subglacial hydrological conditions are reached earlier in the season. Modelling studies including a 'dynamic switching' threshold determine that above a critical rate of meltwater input, channelization and surface deceleration occurs, indicating that sustained high meltwater rates would suppress dynamic response (Schoof, 2010). However, our analysis during two contrasting melt seasons does not completely concur with these findings, suggesting that a more complex relationship between meltwater availability and accelerated flow exists. The spatial and temporal heterogeneity of ice flow presented in this study suggests caution should be exercised when upscaling dynamic properties of glaciers to larger regions.

\section{ACKNOWLEDGEMENTS}

This work was funded by a UK Natural Environment Research Council (NERC) grant and the Greenland Analogue Project (Sub-project A). TSX data used here are publicly available from the MEaSUREs dataset at the US National Snow and Ice Data Center. R. Pettersson is thanked for providing a preliminary basal DEM. The two anonymous reviewers are thanked for constructive comments.

\section{REFERENCES}

Bartholomew I, Nienow P, Mair D, Hubbard A, King MA and Sole A (2010) Seasonal evolution of subglacial drainage and 
acceleration in a Greenland outlet glacier. Nature Geosci., 3(6), 408-411 (doi: 10.1038/ngeo863)

Bartholomew ID and 6 others (2011) Seasonal variations in Greenland Ice Sheet motion: inland extent and behaviour at higher elevations. Earth Planet. Sci. Lett., 307(3-4), 271-278 (doi: 10.1016/j.epsl.2011.04.014)

Das SB and 6 others (2008) Fracture propagation to the base of the Greenland Ice Sheet during supraglacial lake drainage. Science, 320(5877), 778-781 (doi: 10.1126/science.1153360)

Doyle SH and 9 others (2012) Ice tectonics during the rapid tapping of a supraglacial lake on the Greenland Ice Sheet. Cryos. Discuss., 6(5), 3863-3889 (doi: 10.5194/tcd-6-3863-2012)

Hanna E, Huybrechts P, Janssens I, Cappelen J, Steffen K and Stephens A (2005) Runoff and mass balance of the Greenland ice sheet: 1958-2003. J. Geophys. Res., 110(D13), D13108 (doi: 10.1029/2004JD005641)

Harper J, Humphrey N, Pfeffer WT, Brown J and Fettweis X (2012) Greenland ice-sheet contribution to sea-level rise buffered by meltwater storage in firn. Nature, 491(7423), 240-243 (doi: 10.1038/nature11566)

Hasholt B, Mikkelsen AB, Nielsen MH and Larsen MAD (2012) Observations of runoff and sediment and dissolved loads from the Greenland ice sheet at Kangerlussuaq, West Greenland, 2007 to 2010. Z. Geomorph., Supplementary Issue (doi: 10.1127/0372-8854/2012/S-00121)

Hooke RLeB, Calla P, Holmlund P, Nilsson M and Stroeven A (1989) A 3 year record of seasonal variations in surface velocity, Storglaciären, Sweden. J. Glaciol., 35(120), 235-247

Humphrey NF, Harper JT and Pfeffer WT (2012) Thermal tracking of meltwater retention in Greenland's accumulation area. J. Geophys. Res., 117(F1), F01010 (doi: 10.1029/2011JF002083)

Joughin I (2002) Ice-sheet velocity mapping: a combined interferometric and speckle-tracking approach. Ann. Glaciol., 34, 195-201 (doi: 10.3189/172756402781817978)

Joughin I, Das SB, King MA, Smith BE, Howat IM and Moon T (2008) Seasonal speedup along the western flank of the Greenland Ice Sheet. Science, 320(5877), 781-783 (doi: 10.1126/science.1153288)

Joughin I, Smith B, Howat IM, Scambos T and Moon T (2010a) MEASUREs Greenland ice sheet velocity map from InSAR data. National Snow and Ice Data Center, Boulder, CO Digital media: http://nsidc.org/data/docs/measures/nsidc0478_joughin

Joughin I, Smith BE, Howat IM, Scambos T and Moon T (2010b) Greenland flow variability from ice-sheet-wide velocity mapping. J. Glaciol., 56(197), 415-430 (doi: 10.3189/ 002214310792447734)

Leprince S, Barbot S, Ayoub F and Avouac J-P (2007) Automatic and precise orthorectification, coregistration, and subpixel correlation of satellite images: application to ground deformation measurements. IEEE Trans. Geosci. Remote Sens., 45(6), 1529-1558 (doi: 10.1109/TGRS.2006.888937)

Luckman A, Murray T, Jiskoot H, Pritchard H and Strozzi T (2003) ERS SAR feature-tracking measurement of outlet glacier velocities on a regional scale in East Greenland. Ann. Glaciol., 36, 129-134 (doi: 10.3189/172756403781816428)

Moon T, Joughin I, Smith B and Howat I (2012) 21st-century evolution of Greenland outlet glacier velocities. Science, 336(6081), 576-578 (doi: 10.1126/science.1219985)

Palmer S, Shepherd A, Nienow P and Joughin I (2011) Seasonal speedup of the Greenland Ice Sheet linked to routing of surface water. Earth Planet. Sci. Lett., 302(3-4), 423-428 (doi: 10.1016/ j.epsl.2010.12.037)

Rignot E and Kanagaratnam P (2006) Changes in the velocity structure of the Greenland Ice Sheet. Science, 311(5673), 986-990 (doi: 10.1126/science.1121381)

Schoof C (2010) Ice-sheet acceleration driven by melt supply variability. Nature, 468(7325), 803-806 (doi: 10.1038/ nature09618)

Shepherd A, Hubbard A, Nienow P, McMillan M and Joughin I (2009) Greenland ice sheet motion coupled with daily melting in late summer. Geophys. Res. Lett., 36(1), L01501 (doi: 10.1029/2008GL035758)

Strozzi T, Luckman A, Murray T, Wegmuller $\mathrm{U}$ and Werner $\mathrm{CL}$ (2002) Glacier motion estimation using satellite-radar offsettracking procedures. IEEE Trans. Geosci. Remote Sens., 40(11), 2834-2391 (doi: 10.1109/TGRS.2002.805079)

Sundal AV, Shepherd A, Nienow P, Hanna E, Palmer S and Huybrechts P (2011) Melt-induced speed-up of Greenland ice sheet offset by efficient subglacial drainage. Nature, 469(7331), 521-524 (doi: 10.1038/nature09740)

Van As D, Hubbard AL, Hasholt B, Mikkelsen AB, Van den Broeke MR and Fausto RS (2012) Large surface meltwater discharge from the Kangerlussuaq sector of the Greenland ice sheet during the record-warm year 2010 explained by detailed energy balance observations. Cryosphere, 6(1), 199-209 (doi: 10.5194/tc-6-199-2012)

Van de Wal RSW and 6 others (2008) Large and rapid melt-induced velocity changes in the ablation zone of the Greenland Ice Sheet. Science, 321(5885), 111-113 (doi: 10.1126/science. 1158540)

Werner C, Wegmüller U, Strozzi T and Wiesmann A (2001) Gamma SAR and interferometric processing software. In Sawaya-Lacoste $\mathrm{H}$ ed. Proceedings of ERS-ENVISAT Symposium, 16-20 October 2000, Gothenburg, Sweden. European Space Agency, Noordwijk

Zwally HJ, Abdalati W, Herring T, Larson K, Saba J and Steffen K (2002) Surface melt-induced acceleration of Greenland icesheet flow. Science, 297(5579), 218-222 (doi: 10.1126/ science.1072708) 